\title{
Tarbiyah analysis in life: Historical approach and curriculum development
}

\author{
Mohamad Agung Rokhimawan ${ }^{1}$, Istiningsih ${ }^{2}$ \\ ${ }^{1}$ Study Program of Islamic Primary Teacher Education, State Islamic University Sunan Kalijaga Yogyakarta, Indonesia \\ ${ }^{2}$ Study Program of Islamic Education, State Islamic University Sunan Kalijaga Yogyakarta, Indonesia
}

\section{Article Info \\ Article history: \\ Received Jun 13, 2019 \\ Revised Aug 15, 2019 \\ Accepted Oct 7, 2019}

\section{Keywords:}

Curriculum development History

Tarbiyah analysis

\begin{abstract}
The findings of the research are the tarbiyah curriculum journey grouped into eight stages of curriculum development. Starting from the embryo curriculum in 1961, this is the first stage as a curriculum based on the main points of the Pancasila Education System. The second stage of the curriculum, which contains prioritising the mastery of science and technology, has not been focused on formulating its abilities. In the third stage, the paradigm shift to the concept of competency-based curriculum. The college itself developed the fourth stage of the curriculum. The fifth stage is the university curriculum is developed and implemented based on competency for each study program. Sixth, the curriculum of learning achievement is adjusted to the level of KKNI. The seventh stage, the competence of graduates, is determined by referring to KKNI. In the eighth stage, the higher education curriculum contains an equal quality of learning outcomes. Find curriculum design concepts for tarbiyah in the future. Where the eight components of the curriculum concept are Competence Achievement, Continuous Improvement, Functional for users, Adaptable to the social community, Sharing on core values of UIN, Build real scientist. This is all to answer the challenges of developing the tarbiyah curriculum in the future.
\end{abstract}

Copyright () 2019 Institute of Advanced Engineering and Science. All rights reserved.

\section{Corresponding Author:}

Mohamad Agung Rokhimawan,

Study Program of Islamic Primary Teacher Education (PGMI),

State Islamic University Sunan Kalijaga Yogyakarta,

Jl. Laksda Adisucipto, Papringan, Caturtunggal, Depok, Sleman, Daerah Istimewa Yogyakarta, Indonesia.

Email: rokhimawan78@gmail.com

\section{INTRODUCTION}

Higher education is one of the educational units that cannot be separated from culture both within and outside the educational system. The existence of universities in the whole of the nation and state life has a tremendous role through tri dharma of education; those are education, research and community services. In current conditions, the FITK's curriculum is still running triple curriculum, namely: curriculum 2006, curriculum 2012, and curriculum 2017 which now applies. This becomes a problem for Faculty managers because they cannot provide the same policy for graduates in FITK. While the current graduates have already competed with other countries joined in the MEA.

Nuryana pointed out the importance of a hidden curriculum for developing character values, instilling disaster elements, and teaching disaster knowledge and skills as early as possible [1]. In line with Gary from the results of research that emphasises interprofessional activities at the faculty to minimise semester credit shortage conflicts and lecture scheduling conflicts [2]. This activity is one of the solutions taken by the University of Nebraska's Faculty of education. But multicultural education in Finland is oriented towards social justice. It has already surfaced with clear curricular discourse moving towards social justice education where a multicultural perspective is an integrated part of the curriculum. The 2014 curriculum aims 
to foster ethical and respectful students with a sense of fairness and an open attitude towards all types of diversity. Future challenges ensure implementation and advance transformation in curriculum reform [3]. Curriculum development should consider several aspects such as the psychology of child development, the development of sociology, the development of science and technology, the development of employment needs in the community and so on [4].

UIN Sunan Kalijaga has 8 (eight) faculties, one of them are the Faculty of Education and Teacher Training (FITK). This is the oldest faculty at the university with 5 (five) programs on Bachelor degree and Master degree program, those are: Islamic Education (PAI), Arabic Language Education (PBA), Teacher Education of Elementary School (PGMI), Islamic Education Management (MPI) and Early Childhood Education (PIAUD). The next challenge is the revolution of digital technology as the rapid change, from the collapse of the old level and the emergence of new standards, the development of globalisation and internationalisation in all areas. The current FITK's curriculum is based on the IQF (Indonesian Qualification Framework) or KKNI (Kerangka Kurikulum Nasional Indonesia) to match, equate, and integrate competencies between education and job training, as well as work experience in the framework of recognition of work competencies in accordance with the structure of work in various fields.

IQF is a response to changes in the competency-based curriculum, where IQF sets outcome-based curriculum in various educational practices [5]. Of the challenges above arise the problem of how the development of curriculum in the Faculty of Tarbiyah and Teacher Training at UIN Sunan Kalijaga Yogyakarta? How does the Tarbiyah Faculty develop curriculum concepts in the future? What is the history of the establishment of the faculty of tarbiyah and teacher training at UIN Sunan Kalijaga Yogyakarta? The purpose of this article is to answer the challenges of curriculum development going forward and design the concept of Tarbiyah curriculum development in the future until 2042 (25 years) at UIN Sunan Kalijaga Yogyakarta. This article will discuss the Travel Curriculum of Higher Education in Indonesia, developing curriculum, designing curriculum concepts and the life history of the Faculty of Tarbiyah Sciences and the teaching of UIN Sunan Kalijaga Yogyakarta.

\section{RESEARCH METHOD}

This type of research uses library research or library method with a historical approach. Primary data collection techniques directly using direct observation in the field, then looking for curriculum documents in tarbiyah, this data is to reveal the course of academic life in the Faculty of Tarbiyah and Teacher Training at UIN Sunan Kalijaga Yogyakarta. Then take data by reviewing journal journals and travel documents, to answer tarbiyah challenges in the future.

\section{RESULTS AND ANALYSIS}

\subsection{The journey of higher education curriculum in Indonesia}

The journey of the Higher Education Curriculum in Indonesia after the independence of the

Republic of Indonesia (NKRI) is from 1945 until now in 2017. (a) Curriculum-based on the principal of National Education System Pancasila (Law No. 22 of 1961, Presidential Determination No. 19 of 1965 , Presidential Regulation No. 14 of 1965). (b) The Government's regulated curriculum (Law No. 2 of 1989, Regulation No. 60 of 1999). (c) Paradigm shift to KBK concept, Higher education curriculum developed by universities concerned with reference to the national standard of education for each study program (Law No. 20 of 2003 Article 38 paragraph 3 and 4, Kepmendiknas No. 232 / U / 2000 , and changes in core curriculum in Kepmendiknas N.o 045 / U / 2002). (d) Curriculum developed by universities themselves (Regulation No. 19 of 2005 Article 17 paragraph 4, PP 17 of 2010 article 97 paragraph 2). (e) The curriculum is developed based on competence and contains at least five elements of competence (PP No. 17 of 2010 article 97, paragraphs 1 to 3). (f) Achievement of Learning Following the Level of KKNI (Presidential Regulation No. 08 of 2012). (g) Graduate competencies are established concerning KKNI (Act No. 12 of 2012 Article 29). (h) Higher Education Curriculum (PP Ristekdikti No 44 the Year 2015).

The curriculum of higher education in Indonesia has been standardised since 1994 as National Curriculum established by Law No.056 / U / 1994 which contains about IPTEKS prioritisation, not focusing on formulating consortium capability and creating compulsory courses of 100-110 credits of curriculumbased content. According to the decision of the Director-General for the Development of Islamic Religious Development Number: E / 52/95 set the core topic of the IAIN undergraduate (S1) undergraduate curriculum. This decision is a basic guideline and a minimum national reference that must be done by lecturers in the course and further developed by the lecturer [6]. In 2000/2002, it changed back into the core curriculum and Institutional as stipulated in Act no. 232 / U / 2000 and 045 / U / 2002 which contains prioritising the 
achievement of competence, not set limits of knowledge to be mastered, forums of similar study programs determine the main competencies. It is known as a competency-based curriculum [7].

In 2014 it transforms into the Higher Education Curriculum as stated in the Law of Higher Education. 12/2012 and the national standard of higher education in it contain Permendiknas No. 49/2014, which contains priority equality of learning achievement (quality), learning achievement consists of attitude, special skills, and knowledge mastery. In the SNPT set attitude, general skills, similar study formulate special skills and knowledge [7] in addressing the content gap by integrating the existing local curriculum with the national curriculum [8].

\subsection{Curriculum development in Faculty Of Tarbiyah UIN Sunan Kalijaga Yogyakarta covers 8 stages}

First Stage: Curriculum based on the Principles of National Education System of Pancasila (Law No. 22 of 1961, Presidential Determination No. 19 the Year 1965, Presidential Regulation No. 14 the Year 1965). Based on the deliberation of the curriculum in Tarbiyah Faculty on December 9, 1966 at Yogyakarta, attended by Religious Bureau of the Department of Religious Affairs of Jakarta, Cirebon, Malang and Pamekasan and based on the curriculum of Tarbiyah Faculty of IAIN Sunan Kalijaga on January 28, 1967 in Yogyakarta attended by Faculty of Tarbiyah Yogyakarta, Purwokerto and Purworejo, have decided to Tarbiyah IAIN Sunan Kalijaga Faculties and Tarbiyah Faculty of IAIN Sunan Ampel along with their branches, open several majors at the doctoral level according to the level of faculty capability of each that came into force in 1969 in majors such as: Philosophy of Education, Islamic Social Education, Didactic method of Islamic Education, Didactic method of Arabic Language, Management and Supervision of Islamic Education and History of Islamic Education [9].

In Tarbiyah Faculty of IAIN Sunan Kalijaga Yogyakarta, the new religious and Arabic curriculum has been applied at the doctoral level since 1967. The faculty of Tarbiyah who have not opened a course according to the new curriculum, the curriculum still apply with the old curriculum. The impact of the Ministry of Education and Culture Decree number: 0124 / U / 1979 applies the use of the semester credit system at the Tarbiyah Faculty of IAIN Sunan Kalijaga to provide more flexible and varied educational programs so that more students can choose educational programs to go to certain professional levels [10].

The first leader in the Faculty of Tarbiyah IAIN Sunan Kalijaga period I year 1961-1962 led by the Dean Prof. R.H.A Soenarjo, S. H and his secretary Drs. Kafrawi. Then continued in the second period of 1962-1965 conducted by the dean of Prof. H. Muchtar Yahya and vice dean I Drs. Abu Tauchied, MS. In the third period of 1965-1968, the Faculty of Tarbiyah was led by Prof. Ir. H. Muchtar Yahya and represented by Drs. Busyairi Madjidi.

In the period IV Year, 1968-1971 Faculty Tarbiyah led by Drs. Busyairi Madjidi and represented by Drs. Syamsudin. Then continued in the period to-V is the year 1971-1974 conducted by the Dean Drs. A. Soetjipto and Drs. Soerojo is his deputy. VI-Period Year 1974-1979 led by the Dean Drs. A. Soetjipto and vice Dean Drs. Abdullah Dawn. In the period to VII Year 1979-1982 conducted by the Dean Drs. Soerojo, MA and Drs. Rahmat Suyud as his representative. In 1982-1985 or the period to VIII led by Drs. Syamsudin and vice Dean I Drs. Rahmat Suyud. Period to IX Year 1985-1988 led by Drs. Agus Mirwan as the 9th dean. Implementation of curriculum S-1 and procurement of diploma program II Faculty Tarbiyah IAIN Sunan Kalijaga Yogyakarta, in general, the General Elementary Course (MKDU) amounted to 32 SKS. The general basic courses include Pancasila, Curiosity, Dirasah Islamiyah I, II and III, General Philosophy, Basic Social Sciences, Bahasa Indonesia, Arabic, Arabic, English and Basic Nature. Basic Lecture of Kehlian (MKDK) amounted to 48 credits, Professional Skills Courses (MKKP) 76 credits; Elective Courses Each department is loaded with 4 credits [11]. The distribution of the number of courses in each semester is on average 5 to 6 courses and 10 to 14 hours per semester [12].

The Second Stage the curriculum is regulated by the Government or the National Curriculum (Law No. 2 of 1989, Regulation No. 60 of 1999) which contains the priority of IPTEKS mastery, it has not focused on formulating its capability, and the consortium has set the compulsory S1 subject to 100-110 SKS. At this time the Faculty of Tarbiyah led by the 10th Dean. H. Muhammad Anis, M. A, or it happens in the X period Year 1988 - 1993. In XI Period year 1998-2002 the faculty-led by Dr H. R. Abdullah, M. Sc.

Third Stage, the paradigm shifted to the concept of $K B K$, Higher education curriculum developed by universities which concerned with reference to the national standard of education for each study program (Law No. 20 Year 2003 Article 38 paragraph 3 and 4, Kepmendiknas No. 232 / U / 2000, and changes in core curriculum in Kepmendiknas no 045 / U / 2002) conceptualizing the priority of achieving competence and have not determined the limits of science that should be mastered as well as forums of similar programs in determination of major competencies. In 2000 the Faculty of Tarbiyah is still led by Dr H. R Abdullah, M. Sc and experiencing a shift of curriculum that refers to the National Education Standards.

The Fourth Stage of the Curriculum is developed by the university itself (PP No. 19 Year 2005 Article 17 paragraph 4 which states that the curriculum level of educational unit for each study program in 
universities is developed and established by each university with reference to the National Education Standards, and in the Government Regulation (PP) 17 of 2010 article 97 paragraph 2 which reads Curriculum level of educational unit for each program study in universities developed and established by each university with reference to the National Education Standards). In the XII period of 2003-2007, the faculty-led by Drs Rahmad Suyud as the 12th dean.

The Fifth Stage the curriculum is developed and implemented based on competency (PP No. 17 the Year 2010 article 97 paragraph 1-3) each program study develops and establishes itself based on the university by referring to the National Education Standards. Competencies achieved in the curriculum should meet at least 5 elements, namely a) personality base, b) mastery of science, technology, art and/or sport, c) ability and skill of work, d) attitude and behaviour in action according to level of expertise based on knowledge and skills mastered, e.) mastery of the rules of community life in accordance with the choice of expertise in the work. In the XIII period, Faculty of Tarbiyah led by Prof. Dr Sutrisno, M. A.g.

The Sixth Stage of Learning Achievement in accordance with the KKNI Level (Presidential Decree No. 08 of 2012 Article 1 paragraph 1 which reads KKNI is a framework of competency qualification that can be paired, equalize and integrate between the field of education and the field of job training and work experience in the framework of awarding competency work in accordance with the structure of work in various sectors At this stage or the period to XIV, the Faculty of Tarbiyah is still led by Prof. Dr Sutrisno, M. Ag.

The Seventh Stage the competence of graduates is determined by referring to KKNI (UU Higher Education Number 12 Year 2012 article 29 paragraph 1 and 2 which reads: The National Qualification Framework is a learning achievement gap that equates the field of formal, non-formal, informal, or work experience in the framework of the recognition in working competence in accordance with the structure of work in various sectors and paragraph 2 which reads: The National Qualification Framework as referred to in paragraph (1) becomes the primary reference in determining the competence of academic education graduates, vocational education and professional education In 2011-2015 or period XIV Faculty of Tarbiyah is led by Prof. Hamruni, M.Si. 2015-2016 and period XVI led by Dr Tasman Hamami, MA as his representative.

Eighth Phase of Higher Education Curriculum or KPT (Permenristedikti No. 44 Year 2015 on National Standards of Higher Education) which contains about; giving priority to the achievement of learning (quality), learning achievement consists of attitudes, general skills, special skills and knowledge mastery, SNPT set the attitude of general skills, similar studies formulate special skills and knowledge. In this period or period XVII, the tarbiyah faculty is led by Dr Muhammad Arifi, M. Ag and represented by the dean I Dr Istiningsih M.Pd who began to use college curriculum or KPT as a curriculum in the Faculty of Tarbiyah UIN Sunan Kalijaga Yogyakarta.

\subsection{The concept of FITK's curriculum for future in 25 years ahead}

The importance of considering Faculty curriculum reforms to face challenges in the future. To improve the academic services and faculties of the faculty. Attention must be paid to designing curriculum concepts, including 1) faculty guiding principles regarding philosophy and practice; 2) curriculum; 3) multidisciplinary between courses and courses offered in the curriculum; 4) The level of design innovation for faculty sustainability; 5) collaborative networks within each institution, between institutions and the community [13]. This article tries to offer designing concepts or pillars in compiling the curriculum. This concept is assumed to be able to answer the predicted future demands according to the next 25 years.

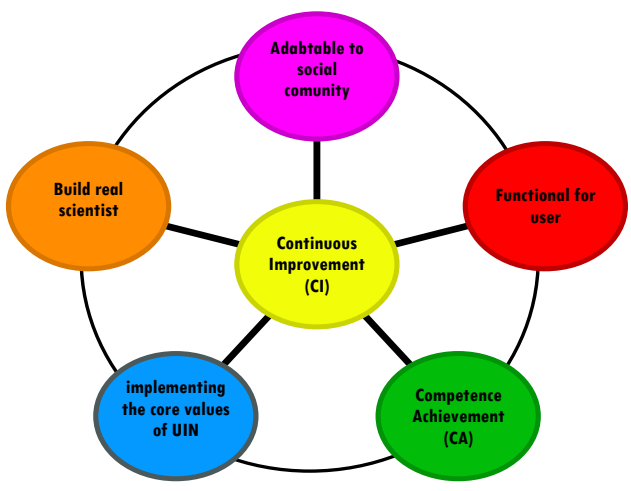

Figure 1. Future Tarbiyah (Faculty of Education) Curriculum Concept 
This research designs the concepts or pillars in preparing the curriculum. This concept is assumed to be able to answer the future demands which are predicted for the next 25 years. There are four pillars and curriculum building; those are:

a. The curriculum should be in continuous improvisation/continuous improvement (CI)

b. The curriculum should be able to fulfil the needs of users. For FITK, the intended graduates are institutions, institutions, education (formal, informal and non-formal education). The proper term for this spirit is functional for the user.

c. The curriculum must be able to answer the competency achievement of Competence Achievement (CA) students for the future. Presented in a curriculum content that contains the competency of creating entrepreneurial opportunities, entrepreneurial attitudes, entrepreneurial knowledge and entrepreneurial spirit [14]. Jeffrey pointed out the importance of curriculum development by developing skills, inclusion-minded habits and spiritual growth, especially for undergraduate education. To enrich and broaden the way we think about undergraduate education and spiral curriculum design, with the ultimate goal of colouring the role of undergraduate pedagogy in shaping academic thinking habits and professional character that we hope students can develop [15].

d. The FITK curriculum must be based on core values of UIN Sunan Kalijaga. The core values of UIN SUKA are currently as follows: Core values of UIN are:

"Integrative-Inter-Connective, Innovative-Innovative, Inclusive-Continuous Improvement"

What is meant by integrative-interconnectivity is a system of integration in academic development, management, student affairs, cooperation, and entrepreneurship. While DedicatedInnovative is to be dedicated, trustworthy, pro-quality, think and move actively, creative, intelligent, and innovative; not just work routinely and diligently. Inclusive-Continuous Improvement is Open, accountable, and committed to change and sustainability. In line with John E. Mitchell multidisciplinary teaching across faculties to provide innovative undergraduate engineering curricula that are centred on problem-based learning programs. This explains the reasons for teaching the elements present in the work of the curriculum framework and how the structure integrates with the existing aspects of the collective curriculum [16].

UIN Sunan Kalijaga Yogyakarta offers an integrative model of education and interconnectivity with an integrated system of academic, management, student affairs, cooperation and entrepreneurship: dedicated-innovative through dedicated, trustworthy, pro-quality, active thinking, active, creative, intelligent and innovative; not only just work routinely and diligently but also has implemented their dedication and innovative while inclusive-continuous improvement is open, accountable and committed for change and sustainability.

According to Amin Abdullah, the implementation of integration-interconnection in the material domain there are three models namely; the integration model into the curriculum package; the integration model into the curriculum package; model naming courses that show the relationship between two general scientific disciplines and Islam; and the model of integration into the themes of the classes [17].

UIN Sunan Kalijaga has been committed for being an inclusive campus by providing an equal opportunity with anyone from different parts of Indonesia and all kinds of cultures, ethnicities and races to be students including persons with different abilities. Thus, this college became a "fortress of diversity" in perspective, life, religion, community and state.

e. The curriculum designed by FITK must be able to produce graduates who are in fact "true graduates", what is meant by the actual scientists of this research are graduates who have compiled scientific works with novelty content (the renewals of knowledge found). This curriculum aims to assist educators in creating and renewing their learning to provide a more complete, holistic, and systemic sustainability education for students of future leaders, decision-makers, educators, and change agents. To develop better mindsets and actions for future generations, we must give students a complete set of sustainability competencies [18].

f. The curriculum must be able to adjust to social conditions (community), including also master science and technology. Currently, the development which is very rapid in the field of Science and Technology is IT. Therefore the curriculum should be able to design graduates who are "able to literate the literacy IT".

\subsection{History of Tarbiyah faculty UIN Sunan Kalijaga Yogyakarta}

Ta'adib, Ta'alim and Tarbiyah these three terms contain the same meaning. In this connection, alAttas (1980) argues that ta'alim only means teaching so that it is more specialised than education. In other 
languages, ta'alim is only part of learning. Meanwhile, at this time, the term tarbiyah is more widely used in Arabic-speaking countries, so it seems too broad. The word tarbiyah is also used in the world of animals and plants to care for or protect, raising and others. The term education in education is only used for humans. According to al-Attas, ta'adib is more appropriate for learning because it is not too specific in terms of teaching only and applies only to humans and does not apply to animals and plants. Also, it is closely related to the state of science in Islam, including the content of education [19]. According to Munir Mulkhan, tarbiyah philosophy was born from the philosophy and theory of the western countries. In the case of the great tradition in tarbiyah, it has grown in history since before humans came to know pedagogy, education, learning, and teaching. Ironically, the practice of tarbiyah education tends to adopt theories that grow and develop in the secularly stamped Western world [20].

History of Tarbiyah Faculty IAIN Al-Jami'ah Yogyakarta is an integral part of the history of the establishment of IAIN itself, as the demand for the development of a faculty of religion in the country. This is also reinforced by the decision of MPRS Number 1 / RIS / MPRS / 1863, appendix A. Ad. 5, which expressly requests the expansion of IAIN [21].

Faculty of Tarbiyah (Education) IAIN Al-Jamiah in Yogyakarta was opened in 1960/1961 and led by Prof. R.H.A Soenarjo, SH who is also the president of IAIN Al-Jamiah in Yogyakarta and the secretary of the faculty by Drs. Kafrawi. Then, since April 16, 1962, the previous of President of Faculty of Tarbiyah (Education) Yogyakarta was handed over to Prof. H. Muchtar Yahya, and his secretary is Drs. Kafrawi [21]. Following the demands and developments of the times, IAIN has been established in various regions; therefore, every IAIN in each part the need to be given their own with different names from IAIN in other areas. Based on the result of the Minister of Religious Affairs No. 26 of 1965 dated June 15, 1965, IAIN AlJami'ah in Yogyakarta was named "Sunan Kalijaga", which came into effect on 1 July 1965. Since then, the Faculty of Tarbiyah (Education) in Yogyakarta named Tarbiyah Faculty or Faculty of Education IAIN Sunan Kalijaga Yogyakarta. Likewise, for the other faculties in their environment [21].

Since its establishment, the education and teaching level in Faculty of education and teacher learning of IAIN Sunan Kalijaga Yogyakarta is arranged and pursued in five years or using the old system with the following provisions: First-year level of Propedeuse (two semesters), Second-year of candidate level (two semesters), third-year Bakaloreat level two semesters), fourth-year of doctoral-level I (two semesters) and fifth-year of doctoral degree II (two semesters).

Students who have completed and graduated on the final examination in the third-year (Bakaloreat), are granted the right to use a Bachelor's Degree (BA). While those who have completed and passed the thesis exam in the fifth year (Doctoral II), can use the Bachelor Degree Complete (Doctorandus). However, after the issuance of the Decree of Rector IAIN Sunan Kalijaga Number 17 Year 1983, which is an implementation and elaboration of the Letter of Resignation of Minister of Religious Affairs No. 97 of 1982 , the system of education and teaching as well as other faculties begin to use the pattern S1 (Strata 1/Bachelor). With the S1 pattern, the education and teaching system uses credit semester (SKS). Such a situation runs until now [21].

The Faculty of Education and Teacher Learning IAIN Sunan Kalijaga or now it is known as UIN Sunan Kalijaga, as the institution of Islamic Higher Education which is leading in the preparation of expert candidates in Islamic education science and professional educational staff. The Faculty of Tarbiyah (Education) was founded in 1951 along with the establishment of IAIN Sunan Kalijaga Yogyakarta which now becomes the State Islamic University (UIN) Sunan Kalijaga. Since its establishment until 2003, it has some alumni from a network more than 5000 people. They spread throughout the archipelago and several neighbouring countries like Malaysia and Thailand. Alumni have served in various sectors of the work following the field of study, that have learned in faculties and other areas according to their respective creativity such as politics, government, journalism, art and even working in national airlines. To strengthen its existence, Faculty of Tarbiyah continues to develop cooperation with various parties, among others with CIDA Canada, USAID USA, USAID Australia and LIPIA Saudi Arabia [22].

The vision of the Faculty of Education and Teacher Learning is to become the leader of an institution in the development of Islamic education in Indonesia, while its mission is to provide education for candidates for Islamic education (PAI), Arabic Language Education (PBA), MIPA (Tadris MIPA) (KI); also conducting superior quality research in the field of Islamic religious education, Arabic education, MIPA education and Islamic sciences; and organizing community service and service programs [22].

Faculty of Tarbiyah (Education) has an adequate facility in supporting the teaching and learning process. Among these facilities are foreign language laboratories, MIPA's laboratories, libraries, an appropriate learning process as well as parks for outdoor teaching and learning. Meanwhile, the lecturers in its faculty consist of some experts in their field, and also they have extensive experience both in Indonesia and abroad, they also educated from S2, S3 to Professor [22]. 
The Faculty of Tarbiyah (Education) has four majors/program study. Those are Islamic Religious Education (PAI), Arabic Language Education (PBA), Islamic Education (KI), Tadris (Education) MIPA. The $P A I$ 's Department prepares the Professional Islamic education staff candidate as religious teachers in madrasah/school, as manager/principal of madrasah/school, or as an education supervisor. The PBA Department prepares candidates for professional Islamic education personnel as Arabic teachers in madrasah/schools, as managers/principals of madrasah/schools, and as education supervisors. Department of Islamic education prepares candidates for experts (philosopher, conception, researchers and developers) Islamic education sciences, and also has the ability as a teacher of Islam in madrasah/school, manager or the head madrassah/school, educational supervisor or expert research and development of Islamic education. While in Tadris majors covers mathematics education, physics education, chemistry and biology education, also preparing professional teachers in MIPA lessons, as well as education managers for madrasah/school [22].

By the efforts of Tarbiyah the Faculty to optimise its function as a pioneer in the world of Islamic education, it was established Central for Developing Islamic Education (CDEI). The ultimate purpose of creating CDEI is to improve the quality of Islamic education in Madrasahs, Pesantrens, Schools, and Universities as well by developing studies and research on Islamic culture, as well as providing educational assistance. The vision of CDEI is to become the centre for the research and development of Islamic education by conducting training, research, facilitation and publication professionally and qualified. Meanwhile, its mission is to be pro-active in empowering Islamic education in a madrasah, pesantren schools and universities, being pro-active in managing studies and research in Islamic knowledge as well as being proactive in providing education assistance [22]

The departments of Tarbiyah Faculty have been established with the stipulation of the Minister of Religious Affairs no. 43 The year 1960 then developed again well in legislation or deliberations. The development of majors at the Faculty of Tarbiyah, especially in the general affairs issues are as follows: (a) In the Minister of Religious Affairs Regulation no. 5 the year 1963 about IAIN, it consists of some majors; Religious Education, Paedagogik, Bahasa Indonesia, Arabic, English, Ethnology or Sociology, and Law or Economics. (b) Working delegation in Ciloto August 1970 decided to develop majors at the Faculty of Tarbiyah as follows: Approve the memorandum of understanding submitted in Cibogo on 10 until 20 August about the need of teachers who are able to teach in the field of: Religious Education, Arabic, Paedagogik, English, Indonesian, Socio-Cultural, Expression, Exacta and Supervision. (c) In the President's Meeting at Ditperta in November 1974 and outlined in the decision of the Director-General of Islamic Guidance no. KEP / D.VI / 218/74, General departments in the Faculty of education and teacher learning were omitted so that the majors on its faculty became: Department of Religious Education and Department of Arabic. (d) Three years after the omission of the general department at the Faculty of Tarbiyah it was felt that the need for the department was urgent. So since 1978 many proposals to reopen the general majors in the Faculty of Tarbiyah in different forums: 1) IAIN research team, 2) Working Meeting of Directorate General of Islamic Institution Development in Cibogo 1979. 3) Workshop 1 development IAIN curriculum at Ciputat March 1979. 4) Seminar Research and Development in the Ministry of Religion Jakarta, March 1979 [23].

In conclusion, the general department of the Faculty of Tarbiyah is as follows: "it is necessary to open a general department on the faculty of tarbiyah to meet the needs of the public teachers in the madrasah in order to maintain the SKB of the Three Ministers on the grounds of the P \& K Department until the last statement has not been able to meet the needs of teachers general teacher.

\section{CONCLUSION}

The development of curriculum faculty of Tarbiyah Science has eight stages. Starting from the year 1961, this is the first stage with the designation of curriculum based on the principal Pancasila Education System (SPNP). The second stage of curriculum that contains the priority of the mastery of science and technology has not focused on formulating its capabilities. The third stage, a paradigm shift to KBK concept. The universities themselves developed the fourth stage of the curriculum. The fifth stage of the curriculum college is designed and implemented based on competency for each course of study. Sixth, the curriculum of learning achievement is adjusted to the level of KKNI. The seventh stage, the competence of graduates, is determined by referring to KKNI. At the eighth stage, the higher education curriculum comprises equality of learning achievement (quality). Find curriculum design concepts for tarbiyah in the future. Where the 8 components of the curriculum concept are Competence Achievement, Continuous Improvement, Functional for users, Adaptable to the social community, Sharing on core values of UIN, Build real scientist. This is all to answer the challenges of developing the tarbiyah curriculum in the future. This research recommends further research to validate the hypothetical capital found. Subsequently, empirical research was done to implement a valid concept. 


\section{ACKNOWLEDGEMENTS}

State Islamic University Sunan Kalijaga Yogyakarta supports this research. The author would like to thank FITK UIN Sunan Kalijaga Yogyakarta and all parties involved in the update of this article.

\section{REFERENCES}

[1] Nuryana, Zalik dan Suyadi, "Character development based on the hidden curriculum at the disaster-prone school," Journal of Education and Learning (EduLearn), vol. 13, no. 2, pp. 219-225, 2019.

[2] Gary L. Beck Dallaghan, et al., "Faculty attitudes about interprofessional education," Medical Education Online, vol. 21, no. 1, pp. 1-7, 2019.

[3] Harriet Zilliacusa, Gunilla Holma and Fritjof Sahlströmb, "Taking steps towards institutionalising multicultural education -The national curriculum of Finland," Multicultural Education Review, vol. 9, no. 4, pp. 231-248, 2017.

[4] Latif, Ikhsan Abdul dkk, "The mathematics teachers' understanding of the learning process based on the 2013 curriculum 2017 revision," Journal of Education and Learning (EduLearn), vol. 13, no. 1, pp. 140-146, 2019.

[5] Solikhah, Imroatus., "KKNI in curriculum based learning outcomes (in Bahasa)," LINGUA, vol. 12, no. 1, pp. 1-22, 2015.

[6] Ditjen Pembinaan Kelembagaan Agama Islam Department Agama RI. 1995., "Core Topics of the National Curriculum of the State Islamic Institute of the Tarbiyah Faculty (in Bahasa)," Jakarta: Proyek Pengembangan Pendidikan Tinggi Agama Islam Jakarta. pp. 3-5

[7] Mohamad Agung Rokhimawan, "Model development curriculum integration S1, S2, S3 Program Study of Islamic Basic Education Referring to KKNI," Dissertation UIN Sunan Kalijaga Yogyakarta, 2017

[8] Katie Chau, Aminata Traoré Seck, Venkatraman Chandra-Mouli and Joar Svanemyr, "Scaling up sexuality education in Senegal: Integrating family life education into the national curriculum," Sex Education, vol. 16, no. 5, pp. 503-519, 2016.

[9] Senat mahasiswa. Curriculum 1970 (in Bahasa), Institut Agama Islam Negeri (IAIN) Sunan KalijagaYogyakarta.

[10] Proyek Pembinaan Perguruan Tinggi Agama/IAIN di Pusat Direktorat Pembinaan Perguruan Tinggi Agama Islam tahun 1981/1982, Evaluasi Sistem Kredit dan Non Kredit IAIN, pp. 119-120, 1981/1982.

[11] Proyek PPTA. "Sunan Kalijaga State Islamic Institute of Higher Education System (in Bahasa)," Panitia Penyelenggara Penataran P4. 1995/1996," pp.121-123, 1995/1996.

[12] Proyek Pembinaan Perguruan Tinggi Agama/IAIN in Pusat Direktorat Pembinaan Perguruan Tinggi Agama Islam tahun 1981. Syllabus Tarbiyah Faculty of the State Islamic Institute (in Bahasa), pp.9-22, 1981.

[13] Ana Thudichum Vasconcelos, "Best practices in design education leads to a new curriculum," The Design Journal, vol. 20, no 1, pp.848-858, 2017.

[14] Ahmad Malekipour, Rezvan Hakimzadeh, Marzieh Dehghani1 and Mohmad Reza Zali, "Analysis of entrepreneurial competency training in the curriculum of bachelor of physical education in universities in Iran," Cogent Education, vol. 5, no. 1, pp.1-15, 2018.

[15] Jeffrey W. Murray, "Skills development, habits of mind, and the spiral curriculum: A dialectical approach to undergraduate general education curriculum mapping," Cogent Education, vol. 3, no. 1, pp.1-19. 2016.

[16] John E. Mitchell, Abel Nyamapfene, Kate Roach and Emanuela Tilley, "Faculty wide curriculum reform: the integrated engineering programme," European Journal Of Engineering Education, pp.1-19, 2019.

[17] Musa Asy'arie dan HM. Amin Abdullah, " Implementation of Integration-Interconnection Paradigm in research 3 (in Bahasa)," Disertasi Lecturer UIN Sunan Kalijaga, Lembaga Penelitian UIN Sunan Kalijaga Yogyakarta, 2002.

[18] Rodrigo Lozano, Michelle Y. Merrill, Kaisu Sammalisto, Kim Ceulemans and Francisco J. Lozano, "Connecting Competences and Pedagogical Approaches for Sustainable Development in Higher Education: A Literature Review and Framework Proposal," Sustainability, vol. 9, no. 10, pp. 1-15, 2017.

[19] Langgulung Hasan, Principles of Islamic Education (in Bahasa), Jakarta: Mutiara Sumber Widya Offset, pp. 4-6, 1992.

[20] Abdul Munir Mulkhan, "Tarbiyah Philosophy Based on Makrifat Intelligence (in Bahasa)," Jurnal Pendidikan Islam, vol. 2, no. 2, pp. 219-239, 2013

[21] Orientation committee and upgrading team P-4.,"Wawasan Alma Mater IAIN Sunan Kalijaga Yogyakarta," Sumbangsih offset. Yogyakarta. pp. 84-88, 1991.

[22] M. Alfatih Suryadilaga dan Fachrudin Faiz, Profil IAIN Sunan Kalijaga Yogyakarta 1951-2004, Yogyakarta: Suka Press Yogyakarta, pp. 42-48, 2004.

[23] Proyek PPTA, "Development of State Islamic Religion Curriculum (in Bahasa)," Jakarta: Project for the Development of Religious university, pp. 35-37, 1979. 


\section{BIOGRAPHIES OF AUTHORS}

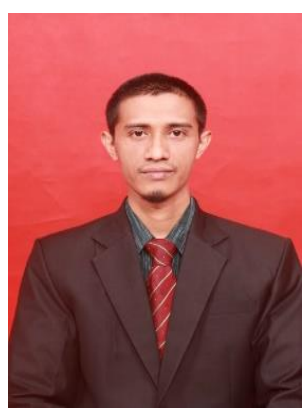

Dr Mohamad Agung Rokhimawan, M.Pd was born in Cirebon, 13 November 1978 completing S1 and S2 in University State Semarang and doctoral Program at UIN Sunan Kalijaga Yogyakarta. Now active as a lecturer in Department of Study Program of Islamic Primary Teacher Education (PGMI) FITK State Islamic University Sunan Kalijaga Yogyakarta. Living in RT. 06 Sumber Batikan Trirenggo Bantu Yogyakarta.

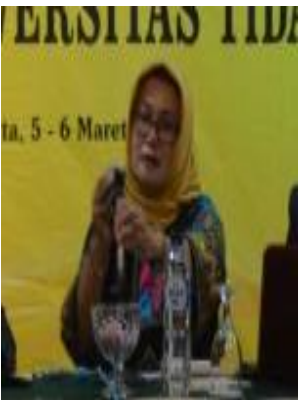

Dr Istiningsih, M.Pd. was born in Sleman, 30 January 1966 Scholar/Level 1 Completed 1990 UTM - FKIP - PBI, Master / Level 2 Completed 2004 UNY - PLS, Doctoral/ level 3. I have completed 2008 UNY - PTK, Postdoc in the University Of Malaya. Now active as a lecturer in Department of Study Program of Islamic Primary Teacher Education (PGMI) FITK State Islamic University Sunan Kalijaga Yogyakarta. I was living in Pundong RT. 1 RW. 4 Tirtoadi Mlati Sleman Yogyakarta. 